International Journal of Biological Sciences

ISSN 1449-2288 www.biolsci.org 2007 3(4):212-224

Research Paper

(C) Ivyspring International Publisher. All rights reserved

\title{
Characterization of transcriptional regulation of neurogranin by nitric oxide and the role of neurogranin in SNP-induced cell death: implication of neurogranin in an increased neuronal susceptibility to oxidative stress
}

\author{
Jingang Guï, Yan Song, Nian-Lin Reena Han, Fwu-Shan Sheu \\ Department of Biological Sciences, National University of Singapore, 14 Science Drive 4, Singapore 117543, Singapore \\ \# Current address: University of Texas, Health Center at Tyler, Tyler 75708, TX, USA.
}

Correspondence to: Dr. Fwu-Shan Sheu, Department of Biological Sciences, National University of Singapore, 14 Science Drive 4, Singapore 117543, Singapore. E-mail address: dbssfs@nus.edu.sg

Received: 2007.01.11; Accepted: 2007.02.23; Published: 2007.02.23

Neurogranin $(\mathrm{Ng})$, a calmodulin (CaM)-binding protein kinase C (PKC) substrate, regulates the availability of $\mathrm{Ca}^{2+} / \mathrm{CaM}$ complex and modulates the homeostasis of intracellular calcium in neurons. Previous work showed $\mathrm{Ng}$ oxidation by NO donor induces increase in $\left[\mathrm{Ca}^{2+}\right]_{\mathrm{i}}$. The current study demonstrated that the gene transcription of $\mathrm{Ng}$ could be up-regulated by various nitric oxide (NO) donors via a NO-soluble guanylyl cyclase (sGC)-mediated pathway. Furthermore, ectopic expression of neuronal nitric oxide synthase (nNOS) in human embryonic kidney 293 cells (HEK 293) exhibited a nNOS-concentration-dependent biphasic regulatory effect on $\mathrm{Ng}$ gene transcription. One of the NO donors, sodium nitroprusside (SNP), however, induced cell death of neuroblastoma Neuro-2a cells. The potency of SNP-induced cell death was shown to be higher in Neuro-2a cells expressing recombinant $\mathrm{Ng}$, as compared with Neuro-2a control cells without $\mathrm{Ng}$ expression in cell viability and apoptosis assays. Single-cell fluorescence imaging and site-directed mutagenesis studies suggest that Ng promotes SNP-induced cell death through an amplification of calcium-mediated signaling, which requires the interaction between $\mathrm{CaM}$ and $\mathrm{IQ}$ motif of $\mathrm{Ng}$. Increased neuronal susceptibility rendered by $\mathrm{Ng}$ in response to pathophysiological NO production is suggested to be involved in the selective vulnerability of neurons to oxidative insults in the CNS.

Key words: neurogranin, $\mathrm{Ca}^{2+} / \mathrm{CaM}$ complex, nitric oxide, IQ motif, cell death, calcium-mediated signaling.

\section{Introduction}

Neurogranin/RC3 $(\mathrm{Ng})$ is a postsynaptic protein that binds to calmodulin (CaM) in the absence of or in low levels of $\mathrm{Ca}^{2+}$. As a $\mathrm{Ca}^{2+}$ capacitor, this protein is implicated in learning and memory by mediating long-term potentiation (LTP) and $\mathrm{Ca}^{2+} / \mathrm{CaM}$-dependent pathways [1-3]. Like many other CaM-binding proteins, $\mathrm{Ng}$ contains an IQ domain interacting with CaM [4]. The CaM-binding affinity of $\mathrm{Ng}$ can be modulated by phosphorylation [5] and oxidation $[6,7]$. The expression of $\mathrm{Ng}$ in the CNS is regulated by thyroid hormone, retinoic acid, and vitamin A $[8,9]$, insufficient of which are closely associated with an age-related decrease in Ng level [10-12]. A thyroid hormone responsive element located in the first intron of the human $\mathrm{Ng}$ gene homolog interferes with T3 trans-activation [13, 14]. Although the presence of several consensus responsive elements for glucocorticoids and retinoic acid were noted in the upstream promoter region of $\mathrm{Ng}$, neither of these hormones influences the transcription of $\mathrm{Ng}$ in mammalian cells [15]. The phorbol ester and PKCs were found to stimulate the transcriptional activity directed by the 5'-flanking sequence of the rat $\mathrm{Ng}$ gene [16]. Transcription factors Sp1 and Sp3 were recently shown to modulate $\mathrm{Ng}$ transcriptional activity [17].

Rat $\mathrm{Ng}$ is a redox-sensitive protein containing four cysteine (Cys) residues that are readily oxidized by nitric oxide (NO) [7]. Oxidation of $\mathrm{Ng}$ forms an intramolecular disulfide bond and, similar to phosphorylation by $\mathrm{PKC}$, reduces the binding affinity for CaM [18]. As a novel biological messenger synthesized by three main isoforms of NO synthase (NOS), $\mathrm{NO}$ can also regulate the expression of various eukaryotic genes [19]. It is of our interests to investigate whether the transcription of $\mathrm{Ng}$ gene, like many other genes, could be regulated by $\mathrm{NO}$ in addition to its biochemical oxidation effect on $\mathrm{Ng}$.

NO exerts both beneficial and damaging effects in the CNS. Excessive NO production can cause oxidative stress in neurons, ultimately impairing neuronal function, and resulting in the neuronal death, which is implicated in many neuronal diseases [20, 21]. As a potential target of $\mathrm{NO}, \mathrm{Ng}$ was suggested to promote calcium-mediated signaling [3] and was found to be a pro-apoptotic factor that increases the intracellular calcium concentration [22]. $\mathrm{Ng}$ was ranked as the top four abundant transcripts, constituting $0.36 \%$ of the total transcripts, more than its binding target calmodulin $1(0.17 \%)$ and $3(0.12 \%)$, in 
the mice cortex [23], suggesting that pharmacological treatment by $\mathrm{NO}$ to neurons expressing $\mathrm{Ng}$ is likely to observe an effect of its expression profile and cellular functions. Indeed, exogenous expression of $\mathrm{Ng}$ in neuroblastoma cells (Neuro-2a) was shown to amplify the intracellular calcium elevation induced by $\mathrm{NO}$ donors [24]. Therefore, it is of great interest to further investigate if $\mathrm{Ng}$ exhibits any relevance to NO-induced neuronal death. Our data in the present study not only reveal that NO could modify Ng transcription activity but also support our hypothesis that $\mathrm{Ng}$, by interacting with CaM through its IQ motif, boosts neuronal vulnerability to the pathophysiological NO insults via amplifying calcium-mediated signaling.

\section{Materials and Methods}

\section{Chemicals}

Dimethyl sulfoxide (DMSO) was purchased from Sigma-Aldrich (Singapore). ( \pm )-S-nitroso-N-acetylpenicillamine (SNAP), sodium nitroprusside (SNP), (Z)-1-[N-(3-Ammoniopropyl)-N-[4-(3-aminopropylam monio)butyl]-amino]diazen-1-ium-1,2-diolate (Spermine NONOate), 1-Hydroxy-2-oxo-3-(N-3-methyl-aminopropyl)-3-methyl-1-triazene (NOC-7), (Z)-1-[N-Methyl-N-[6-(N-methylammoniohexyl) amino]]diazen -1-ium-1,2-diolate (NOC-9), 3-morpholinosydnonimine. $\mathrm{HCl}$ (SIN-1.HCL), 4-Phenyl-3-furoxancarbonitrile, (+/-)-(E)-4-ethyl-2-[(E)-hydroxyimino]-5-nitro-3-hexenamide (NOR-3), 1H-[1, 2, 4] oxadiazolo [4, 3-a] quinoxalin-1-one (ODQ), A23187, were purchased from Calbiochem/EMD Biosciences (San Diego, CA). Each chemical was freshly dissolved either in phosphate buffered saline (PBS) or DMSO according to the manufacturer's instruction and was used immediately.

\section{Molecular cloning}

For constructing the reporter plasmid with a 5 '-flanking sequence of the mouse $\mathrm{Ng}$ gene, the mouse (Swiss albino) genomic DNA was extracted by $\mathrm{Nu}-$ cleoSpin ${ }^{\circledR}$ Tissue Kit (Macherey-Nagel, Düren, Germany). A 258 bp 5'-flanking sequence of mouse $\mathrm{Ng}$ gene $(+3$ to +260$)$ was amplified by PCR using the following primers (forward, 5' GCTTGGCTGTTTGAGG TCC 3'; reverse, 5' GTGTTGAGGGTCCTTGGCT 3'). The PCR product was cloned into the pGEM-T vector (Promega, Madison, WI) and named pGEM-T-pNg (F). Plasmid pGEM-T-pNg (F) was used as a template for PCR and primed with following forward and reverse primers with Sac I and Xho I enzyme linkers, respectively (forward, 5' TAGGAGCTCGGTCCTCGCTCCAGTTCT 3'; reverse, 5' TGTTCTCGAGTGCCGGTGTTGAGGGTC $3^{\prime}$ ). The PCR product was purified and then digested by Sac I and Xho I and cloned into the pGL3-basic vector (Promega) digested by the same two enzymes. The final reporter construct was named pGL3-pNg (+3) and used in every promoter activity analysis experiment. For constructing a mammalian expression vector encoding wild type (WT) $\mathrm{Ng}$ protein, plasmid pET3b-Ng was used for PCR as a template.
PCR was carried out using a forward primer corresponding to the start codon region of $\mathrm{Ng}$ with an upstream Nhe I site linker. The $3^{\prime}$ primer was complementary to the stop codon region of $\mathrm{Ng}$ and contained a downstream Sac II site linker (forward, 5' TAAGCTAGCATGGACTGCTGCACGGAGAGCGCCTGCTCCAAGCCA $\quad 3^{\prime}$; reverse, 5' TAACCGCGGCTAGTCTCCGCTGG $3^{\prime}$ ). The PCR product was double digested by Nhe I and Sac II and linked with double cut (Nhe I and Sac II) pIRES2-EGFP vector (Clontech, Palo Alto, CA) by T4 ligase. The final expression plasmid was named pIRES2-WTNg-EGFP. For generating a plasmid encoding $\mathrm{Ng}$ with four Cys residues mutation $\left(\mathrm{Cys}^{3}\right.$, $\mathrm{Cys}^{4}, \mathrm{Cys}^{9}$ and $\mathrm{Cys}^{51}$ were mutated to glycine), two consecutive steps were performed. The first step followed the same procedure that was used for generating the WT Ng expression plasmid except the forward primer contained single base substitutions for the codons of $\mathrm{Cys}^{3}, \mathrm{Cys}^{4}$, and $\mathrm{Cys}^{9}$ (5' $^{\prime}$ TAAGCTAGCATGGACGGCGGCACGGAGAGCGCCGGCTCCAAGCCA3 $3^{\prime}$ ). The $\mathrm{Cys}^{51}$ mutation was generated in the second step with the same strategy described previously [6]. The final plasmid containing coding sequence for $\mathrm{Ng}$ with mutations of all four Cys residues was named pIRES2-tetra-Ng-EGFP. The plasmid for expressing an I33Q mutation of $\mathrm{Ng}$ was made according to a previous method [4] using a GeneTailor ${ }^{\mathrm{TM}}$ Site-Directed Mutagenesis System (Invitrogen, Carlsbad, CA).

\section{Cell cultures}

HEK293, neuroblastoma Neuro-2a and hypothalamic GT1-7 cells were cultured in Dulbecco's modified Eagle's medium (DMEM) supplemented with 10\% $(\mathrm{v} / \mathrm{v})$ heat-inactivated fetal bovine serum (FBS), 25 mM HEPES, $3.7 \mathrm{~g} / \mathrm{L} \mathrm{NaH} \mathrm{CO}, 100 \mathrm{u} / \mathrm{ml}$ penicillin and $100 \mu \mathrm{g} / \mathrm{ml}$ streptomycin', with a final $\mathrm{pH}$ of 7.0-7.1. Cells were cultured in a humidified incubator with 5\% $\mathrm{CO}$ at $37^{\circ} \mathrm{C}$. The Neuro-2a clone1 cells were cultured with an addition of $0.5 \mathrm{mg} / \mathrm{ml} \mathrm{G} 418$ antibiotic in the medium to maintain a selective pressure. For culturing primary cortical neurons, postnatal day 1 mice (Swiss albino) were decapitated and the cortical regions of the brain were carefully taken out. The cortical tissues were minced and immediately put into PBS solution containing $1 \%$ penicillin/streptomycin and 10 $\mathrm{mM}$ glucose with a steady oxygen perfusion for recovering the cells. After that, the cortical tissue was pelleted and trypsinized in a solution containing $0.1 \%$ (w/v) trypsin with $600 \mu \mathrm{l} 10 \mathrm{U} / \mathrm{ml}$ DNase I dissolved in DMEM. After $20 \mathrm{~min}$ of incubation at $37^{\circ} \mathrm{C}$, the tissue was mechanically dissociated and rinsed four times in PBS solution containing antibiotics and glucose. The cells were seeded on poly-L-lysine (50 mg/L) coated $35 \mathrm{~mm}$ culture dishes (BD Biosciences, Franklin lakes, NJ) and cultured in DMEM containing F12, N2 supplement and $10 \%$ heat-inactivated FBS at $37^{\circ} \mathrm{C}$ with humidity of $5 \% \mathrm{CO}_{2}$. After cells attached to the bottom of the dishes, ${ }^{2}$ cytosine arabinonucleoside (Sigma) was added to the medium at a final concentration of $25 \mu \mathrm{M}$ to inhibit the growth of neuroglia. 
One half of the medium was replaced with fresh medium every other day.

\section{Transient transfection and luciferase activity measurement}

All transfections were preformed at $80 \%$ cell confluence using TransIT-LT1 transfection reagent (Mirus, Madison, WI) according to the manufacturer's instructions. For experiments involving luciferase assays, 2 $\mu \mathrm{g}$ reporter plasmid pGL3-pNg $(+3)$ was transfected into mammalian cells cultured on 6-well culture plates (Nunc, Roskilde, Denmark). One hundred and fifty nanograms of the renilla luciferase expression plasmid pRLSV40 (Promega) was co-transfected as a reference plasmid for normalizing transfection efficiency. NO donors were applied to the culture at $24 \mathrm{~h}$ post-transfection for $4 \mathrm{~h}, 12 \mathrm{~h}$ or $24 \mathrm{~h}$ according to experimental requirements. For pharmacological inhibition experiment, $10 \mu \mathrm{M}$ ODQ was added in the medium $4 \mathrm{~h}$ before NOR-3 application and continue to co-culture with NOR-3. For some transfections, a plasmid expressing neuronal NOS (nNOS), pcDNA3.1-nNOS, was co-transfected with reporter plasmid and pRLSV40. Unless otherwise mentioned, cells were harvested $48 \mathrm{~h}$ post-transfection and lysed for luciferase assay and/or Western blotting. The luciferase activity was measured by a Turner TD 20/20 luminometer (Promega) using the Dual-Luciferase Reporter Assay System (Promega) according to the manufacturer's instructions. For transfections of Ng-expressing plasmids for single-cell calcium imaging, $3 \mu \mathrm{g}$ of each plasmid was used to transfect Neuro-2a cells grown on poly-L-ornitheine (Sigma) coated $13 \mathrm{~mm}$ plastic coverslips (Nunc) placed in $35 \mathrm{~mm}$ culture dishes. For cell viability assays, $1 \mu \mathrm{g}$ of each $\mathrm{Ng}$ expression plasmid was used to transfect Neuro-2a cells cultured in 48-well culture plates (Nunc).

\section{Western blotting}

Total protein was extracted from cultured mammalian cells by modified radioimmunoprecipitation (RIPA) buffer (50 mM Tris-HCl pH 7.4, 1\% NP-40, $0.25 \% \mathrm{Na}$-deoxycholate, $150 \mathrm{mM} \mathrm{NaCl}, 1 \mathrm{mM}$ EDTA, 1 $\mathrm{mM}$ Phenylmethylsulphonyl fluoride, $1 \mu \mathrm{g} / \mathrm{ml}$ Aprotinin, $1 \mu \mathrm{g} / \mathrm{ml}$ Pepstatin A, $1 \mathrm{mM} \mathrm{Na} \mathrm{VO}, 1 \mathrm{mM}$ $\mathrm{NaF}$ ). One tablet of cocktail protease inhibitor (KPL, Gaithersburg, MD) was added to the buffer immediately before use. In brief, for a $10 \mathrm{~mm}$ culture dish, 200 $\mu l$ RIPA buffer (volume was adjusted accordingly in 6-well and 48-well culture plates) was added and cells were detached by a cell scraper. Mixture was transferred into a $1.5 \mathrm{ml}$ eppendorf tube and incubated on an orbital shaker at room temperature (RT) for $15 \mathrm{~min}$. The mixture was thawed after being frozen overnight at $-20^{\circ} \mathrm{C}$ and centrifuged at $10000 \mathrm{~g}$ for $15 \mathrm{~min}$ at $4^{\circ} \mathrm{C}$. The cell debris was discarded and the concentration of protein in the supernatant was measured by Bradford protein assay reagent (Bio-Rad). An aliquot of $50 \mu \mathrm{g}$ protein sample was frozen at $-80^{\circ} \mathrm{C}$ or immediately analyzed by Western blotting. For experiment of analyzing nNOS, total protein was boiled at $95^{\circ} \mathrm{C}$ for 5 min in protein sample buffer $(5 \times$ sample buffer: $2 \mathrm{ml}$ $20 \%$ SDS, $2.5 \mathrm{ml} 0.5 \mathrm{M}$ Tris- $\mathrm{HCl} \mathrm{pH} 6.8,1 \mathrm{ml}$ $\beta$-mercaptoethanol, $2.5 \mathrm{ml}$ glycerol). Denatured protein was chilled on ice for $5 \mathrm{~min}$ and separated on $12 \%$ SDS-polyacrylamide gel by a SE 250 vertical electrophoresis apparatus (Hoefer, San Francisco, CA). For analyzing $\mathrm{Ng}$ expression, protein was separated in non-reducing 10\%-20\% gradient SDS-polyacrylamide. Bromophenol blue and $\beta$-mercaptoethanol were omitted in sample buffer and boiling of sample was avoided. Protein was transferred to Hybond-C nitrocellulose membrane (Amersham Biosciences, Piscataway, NJ). The membrane was then peeled off from the gel and rinsed with $1 \times$ TBST (TBS plus $0.05 \%$ Tween 20 ) once and blocked in $1 \times$ TBST with $5 \%$ nonfat dry milk overnight at $4^{\circ} \mathrm{C}$ on a rocking platform. The blot was then incubated with rabbit polyclonal anti-nNOS (at a 1:5000 dilution; Zymed laboratories, San Diego, CA) or rabbit polyclonal anti-Ng (at a 1:1500 dilution; made from the synthetic peptide of the $C$ terminal 66-78 amino acid sequence of $\mathrm{Ng}$, Biogen, Germany). After washing three times with $1 \times$ TBST, the blot was incubated with horseradish peroxidase-conjugated anti-rabbit IgG (Chemicon, Temecula, CA) at a 1:10,000 dilution for $2 \mathrm{~h}$ at RT. Detection of immunoactive bands was performed by incubating the blot with SuperSignal West Pico Chemiluminescent Substrate solution (Pierce, Rockford, IL) for $2 \mathrm{~min}$, followed by exposure to CL-X Posure ${ }^{\mathrm{TM}}$ Film (Pierce). For reprobing experiments to correct the protein loading difference, blots were stripped in stripping buffer $(1.56 \mathrm{ml} \quad 1 \quad \mathrm{M}$ Tris $\mathrm{pH}$ 6.7, $175 \mu \mathrm{l}$ $\beta$-mercaptoethanol, $5 \mathrm{ml} \mathrm{10 \%} \mathrm{SDS,} \mathrm{bring} \mathrm{up} \mathrm{to} 25 \mathrm{ml}$ with double distilled $\mathrm{H}_{2} \mathrm{O}$ ) and incubated with anti-a-tubulin (clone DM1A, Sigma).

\section{Cell viability and apoptosis assays}

MTT reduction assay. Cells were counted by a hemocytometer and equally distributed in 48-well plates at a density of $5 \times 10^{4}$ cells/well and treated with various concentrations of SNP for $12 \mathrm{~h}$, or A23187 for $24 \mathrm{~h}$. To determine cell viability, the DMEM medium was removed and cells were incubated with 3-(4,5-dimethyl-2-thiazolyl)-2,5-diphenyl-2H-tetrazolium bromide (MTT, Sigma) at a final concentration of $0.5 \mathrm{mg} / \mathrm{ml}$ in phenol-red-free RPMI 1640 medium (Hyclone, Logan, UT) containing 10\% heat-inactivated FBS for $2 \mathrm{~h}$ in the dark at $37^{\circ} \mathrm{C}$. Then $200 \mu \mathrm{l}$ dissolving buffer ( $11 \mathrm{~g}$ SDS in $50 \mathrm{ml}$ of $0.02 \mathrm{M}$ $\mathrm{HCl}$, mixed with $50 \mathrm{ml}$ isopropanol) was added to the wells with gentle trituration. Cultures were incubated with the dissolving buffer at RT in the dark for 1 hour. After the formazan dye was totally dissolved, the solution was transferred to a 96-well Elisa plate (Nunc) and read at $570 \mathrm{~nm}$ by a Spectra Max 340 microplate reader (Molecular Devices, Sunnyvale, CA). In MTT assays for the cells transiently transfected with expression plasmid of WT Ng and $\mathrm{Ng}$ derivatives bearing I33Q or 4 Cys residues mutation, total protein in the parallel culture plates (with plasmid transfection but without SNP treatment) was extracted and used in Western blotting with polyclonal anti-GFP (Upstate, 
Milton Keynes, UK). Signals on immunoblot were quantified by densitometric measurement and used to normalize the transfection difference in each MTT assay.

DNA fragmentation assay. Apoptotic cells were collected by centrifugation at $1500 \mathrm{~g}$ for $5 \mathrm{~min}$. The cell pellet was washed once with PBS and lysed by a solution containing $10 \mathrm{mM}$ EDTA, $5 \mathrm{mM}$ Tris- $\mathrm{HCl}$ (pH 8.0) and $0.5 \%$ Triton X-100 for $30 \mathrm{~min}$ on ice. Sample was centrifuged and the supernatant (low molecular weight DNA) was separated from the pellet (high molecular weight DNA). Both fractions were digested with RNase A (500 U/ml) for $1 \mathrm{~h}$ at $37^{\circ} \mathrm{C}$ and then digested with proteinase $\mathrm{K}(0.5 \mathrm{mg} / \mathrm{ml})$ for $3 \mathrm{~h}$ at $50^{\circ} \mathrm{C}$. The sample was extracted by phenol and phenol/chloroform/isoamyl alcohol (25:24:1, V/V/V), precipitated with 2.5 volume of $95 \%$ ethanol and $1 / 10$ volume of sodium acetate (3M, $\mathrm{pH} 5.2)$, and then dissolved in Tris-EDTA buffer (10 mM Tris- $\mathrm{HCl}$ pH 7.5, 1 $\mathrm{mM}$ EDTA $\mathrm{pH}$ 8.0). DNA was electrophoresed in 1.5\% agarose gel in $1 \times$ TBE buffer. The gel was stained with ethidium bromide ( $2 \mathrm{mg} / \mathrm{L}$ ) for $15 \mathrm{~min}$ and distained 20 min with Milli-Q water. DNA fragments were visualized under UV light and documented.

\section{Quantitative real-time PCR}

Primary cortical neurons on the 12th day of culture were incubated either with $200 \mu \mathrm{M}$ NOR-3 or DMSO in medium for $24 \mathrm{~h}$. After the treatment, the medium containing NOR-3 or DMSO and the medium in the non-treated control were immediately replaced with fresh medium and cultures were kept in a $\mathrm{CO} 2$ incubator for another $12 \mathrm{~h}$. The cortical neurons then were washed once with PBS, and total RNA was extracted using TRIzol reagent (Invitrogen) according to the manufacturer's protocol. DNase I treated RNA was reverse transcribed with Superscript II (Invitrogen). Real-time PCR was performed using syber green real-time PCR mix (Applied Biosystems, Foster City, CA). Primers for Ng are (forward, 5' TCCAAgCCAgACgACgATATT 3'; reverse, 5' CACACTCTCCgCTCTTTATCTTC $3^{\prime}$ ). Primers for the housekeeping gene $\beta$-actin are (forward, 5'CAGCCCTCCTTCCTCGGTAT $3^{\prime}$ Reverse, 5'GATGTCCACGTCACACTTCATGAT 3'). In brief, $10 \mu \mathrm{l}$ of each diluted cDNA was added to $12.5 \mu \mathrm{l}$ SYBR green PCR mixtures with $1.5 \mu \mathrm{l} \mathrm{H}_{2} \mathrm{O}$, and $1.25 \mathrm{pmol}$ primer mix. PCR reactions were performed with the ABI Prism 7000 sequence detection system (Applied Biosystems). Quantitative analyses of target genes were done by using a standard curve for $\beta$-actin, which was compared with a target gene curve using triplicate samples in each cDNA dilution. In all experiments, non-template controls were run together with the samples.

\section{Single-cell fluorescence imaging}

Transiently transfected Neuro-2a cells grown on coverslips were washed twice with $1 \times$ PBS and cultured in indicator-free RPMI 1640 medium with 10\% heat-inactivated FBS. One micromolar calcium dye x-rhod-1 (AM) (Molecular Probes, Eugene, OR) was dissolved in DMSO and loaded into the cells by incubation at $37^{\circ} \mathrm{C}$ with $5 \% \mathrm{CO}$ for $1 \mathrm{~h}$. Before fluorescence measurements, cells were washed in indicator-free RPMI 1640 to remove any dye that was nonspecifically attached to the cell surface, and then incubated for a further $30 \mathrm{~min}$ to allow complete de-esterification of intracellular AM esters. After that, the medium in the culture dish was removed and replaced with Krebs buffer (20 mM HEPES pH 7.4, 145 $\mathrm{mM} \mathrm{NaCl}, 10 \mathrm{mM}$ glucose, $5 \mathrm{mM} \mathrm{KCl}, 2 \mathrm{mM} \mathrm{CaCl}$, $1.3 \mathrm{mM} \mathrm{MgCl}_{2}$, and $\left.1.2 \mathrm{mM} \mathrm{NaH}{ }_{2} \mathrm{PO} 4\right)$. Fluorescence measurements were performed at RT with an upright E600FN microscope (Nikon, Japan) installed with a HBO 100w/2 mercury bulb (Osram, Munich, Germany) and a Fluor $40 \times(0.80 \mathrm{~W})$ water-immersion objective lens. Images were acquired by a 12-bit SensiCam cooled CCD camera (PCO, Molecular Devices) and analyzed using Axon Imaging Workbench (AIW) software. Region of Interest (ROI) was drawn using a Chroma 41017 filter set (Chroma, Rockingham, VT). Fluorescence was measured with excitation at 550nm and emission at 580nm using a Chroma 31004 filter set (Chroma). Changes of the fluorescence intensity were recorded as $\mathrm{F} / \mathrm{F}_{0}$ by a non-ratiometric protocol defined by AIW software. SNP was added slowly without disturbing the cells on the plastic coverslips.

\section{Statistics}

One-way ANOVAs were used to test for differences between experimental groups. Where appropriate, data were compared with Student's $t$-test. Data are expressed as the mean \pm SEM. The $p$ value $<0.05$ was considered to be significant.

\section{Results}

\section{Nitric oxide donors regulate $\mathrm{Ng}$ promoter activity in HEK 293 cells and $\mathrm{Ng}$ transcription in primary cortical neurons}

To examine the possibility that NO donors modify $\mathrm{Ng}$ transcriptional activity, various $\mathrm{NO}$ donors at $200 \mu \mathrm{M}$ were applied to cell culture for $24 \mathrm{~h}$. Ng promoter activities measured by the firefly luciferase activity were shown to be up-regulated by 1.3 fold with SNAP, 1.4 fold with SIN-1.HCL and 1.9 fold with NOR-3 (Fig. 1a). Other NO donors, such as NOC-7, NOC-9, and spermine NONOate, did not exhibit significant influence on the $\mathrm{Ng}$ promoter activity as compared to the control group treated only with PBS. Data were not obtainable due to massive cell death in SNP and 4-Phenyl-3-furoxancarbonitrile treated groups for $24 \mathrm{~h}$ at the same cultured conditions. To further confirm our result, we tested whether the NO donor with highest stimulation on $\mathrm{Ng}$ promoter, NOR-3 is able to up-regulate $\mathrm{Ng}$ transcription in primary cortical neurons that have basal expression of $\mathrm{Ng}$ to show its physiological relevance. Real-time PCR showed that the relative abundance of $\mathrm{Ng}$ mRNA was increased by 1.6 fold in primary neurons treated with NOR-3 as compared to the non-treated control group (Fig. 1b). Various lines of evidence showed that NO exerts one of its cellular actions by binding to the 
heme moiety of the enzyme soluble guanylyl cyclase (sGC), which causes an accumulation of cyclic guanosine monophosphate (cGMP) and leads to a wide diversity of biological functions [25, 26]. To study the involvement of sGC on NO-induced $\mathrm{Ng}$ transcriptional activity, we examined how NOR-3 would influence on $\mathrm{Ng}$ promoter activity in the presence of the sGC inhibitor, ODQ [27], at a concentration of $10 \mu \mathrm{M}$. Fig. 1c showed that with $4 \mathrm{~h}$ pre-treatment with ODQ and co-incubation with NOR-3, the up-regulation of $\mathrm{Ng}$ promoter activity by NOR-3 in HEK 293 cells was markedly inhibited. In our hands, $10 \mu \mathrm{M}$ ODQ alone was unable to modify $\mathrm{Ng}$ promoter activity as compared with the control group which was treated either with DMSO or PBS. That the NO-induced $\mathrm{Ng}$ promoter activity could be inhibited by ODQ suggested that the up-regulation of $\mathrm{Ng}$ promoter activity by exogenous NO stimulation is through a sGC-dependent pathway.

Figure 1. Analysis of $\mathrm{Ng}$ promoter activity upon NO donor stimulation in HEK 293 cells and Ng mRNA abundance in primary cortical neurons. (a) $\mathrm{Ng}$ promoter activity was measured in HEK 293 cells stimulated with various kinds of NO donors (indicated below each bar) at $200 \mu \mathrm{M}$ concentration for 24 h. (b) Relative Ng mRNA abundance in 12-day cultured cortical neurons with NOR-3 treatment for $24 \mathrm{~h}$ was assessed by real-time PCR. PCR results were represented as relative folds of mRNA level over non-treated group (arbitrarily assigned as 1 fold). (c) $\mathrm{Ng}$ promoter activities were measured in HEK 293 cells with stimulation of ODQ alone or NOR-3 in the presence or absence of ODQ. Data are represented as means \pm SEM $(n=3)$ and tested by Student's $t$-test. $* * \mathrm{p}<0.01, * * * \mathrm{p}<0.001$ (compared with the control group).

\section{nNOS exhibits a concentra-}

\section{tion-dependent biphasic effect on $\mathrm{Ng}$ promoter ac- tivity}

Given the effect of exogenous NO on the transcriptional activity of $\mathrm{Ng}$ shown above, it is necessary to know whether endogenous NO produced by nNOS in the same cellular system has similar effects on $\mathrm{Ng}$ promoter activity. To answer this question, an expression plasmid encoding for $\mathrm{nNOS}$ was cotransfected to HEK 293 cells with the reporter construct containing the $\mathrm{Ng}$ promoter, in such a way that the correlation between nNOS expression level and Ng promoter ac-

(a) tivity could be delineated. As shown in Fig. 2a, changes of $\mathrm{Ng}$ promoter activity were largely dependent on the protein level of nNOS ectopically expressed in HEK 293 cells. Ng promoter activity increased significantly when 0.5 or $1 \mu \mathrm{g}$ of the nNOS
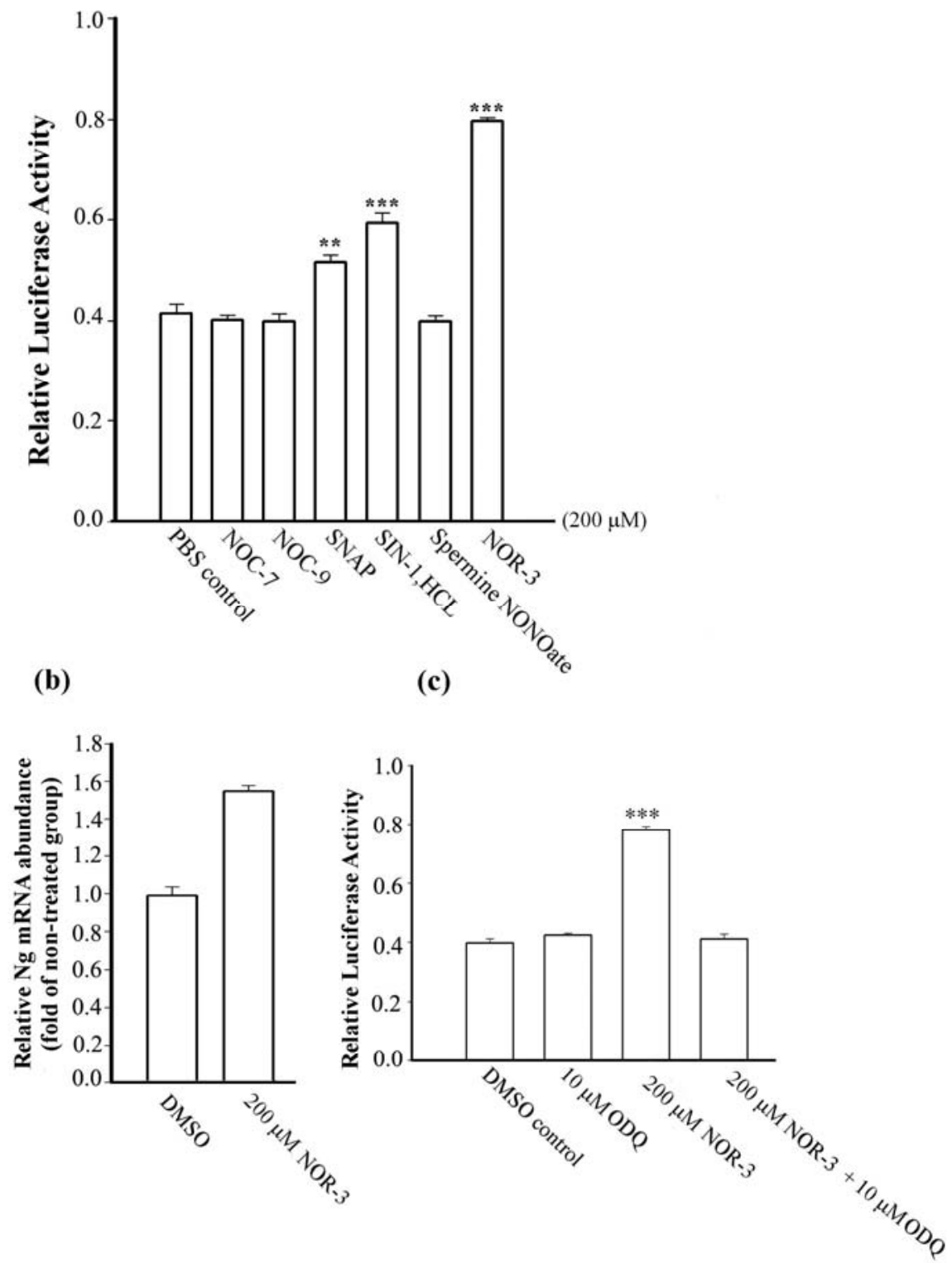

cDNA was transfected. However, the up-regulation was attenuated by higher amount of nNOS cDNA (2 $\mu \mathrm{g}$ and $3 \mu \mathrm{g}$ ) transfected. As evidenced by Western blotting in Fig. $2 b$, the quantity of nNOS expression plasmid transfected was closely in proportion to the expression level of nNOS in the cell. Data illustrated that $\mathrm{Ng}$ promoter activity was transactivated by low threshold level of nNOS expression while higher expression of nNOS in HEK 293 cells was unable to further up-regulate $\mathrm{Ng}$ promoter activity. Experiments on Neuro-2a cells showed the similar regulatory pattern (data not shown). These results suggest that $\mathrm{Ng}$ promoter activity could be regulated with a biphasic 
pattern depending on a certain threshold level of endogenous NO production by nNOS.

Figure 2. nNOS exhibits a dose-dependent biphasic effect on $\mathrm{Ng}$ promoter activity. (a) $\mathrm{Ng}$ promoter activities were measured in HEK 293 cells with cotransfection of indicated concentrations of pcDNA3.1-nNOS. The total amount of plasmid transfected was normalized with pcDNA3.1 vector. Data are shown as means \pm SEM $(n=6)$ and processed with one-way ANOVA followed by post-hoc analyses of Student's $t$-test. $* * * \quad \mathrm{p}<0.001$ (compared with the control pcDNA3.1 vector group). (b) Representative nNOS protein expression levels in HEK 293 cells cotransfected with pcDNA3.1 vector in lane $1,3 \mu \mathrm{g}$, or pcDNA3.1-nNOS plasmid in: lane 2, $0.5 \mu \mathrm{g}$; lane $3,1 \mu \mathrm{g}$; lane $4,2 \mu \mathrm{g}$ and lane $5,3 \mu \mathrm{g}$. Aliquots of extracted protein were used either for luciferase measurement as shown in panel (a), or for Western blotting using nNOS antibody as shown in this panel. Western blotting for $\alpha$-tubulin was used as a loading control.

\section{High dose of NO donor SNP suppresses Ng pro- moter activity in the presence of $\mathrm{Ng}$ protein}

For many years, investigators have been unsuccessful in finding a cell line with endogenous expression of $\mathrm{Ng}$. It was revealed that $\mathrm{Ng}$ mRNA was induced by T3 in the hypothalamic cell line GT1-7. Unfortunately, no $\mathrm{Ng}$ was detected at a translational level even with a T3 treatment [15]. The clone1 cell used in the present study is a stably Ng-expressing Neuro-2a cell line [24]. Our previous data has shown that upon SNP treatment in short duration of $3 \mathrm{~min}$, Ng-expressing Neuro-2a cells showed amplified calcium elevation versus the control Neuro-2a cells without $\mathrm{Ng}$ expression. We suspected that this modulated calcium signaling by $\mathrm{Ng}$ expression upon $\mathrm{NO}$ treatment might have some influence on $\mathrm{Ng}$ transcription. The present results revealed that SNP exhibited a differential effect on the $\mathrm{Ng}$ promoter activity (expressed by relative luciferase reporter assay) between the Ng-free Neuro-2a cells and the Ng-expressed clone1 cells. The histogram in Fig. 3a showed that upon treatment with SNP for $4 \mathrm{~h}$ at a concentration range from 0.2 to $20 \mu \mathrm{M}, \mathrm{Ng}$ promoter activity was neither significantly changed in Neuro-2a cells nor in clone1 cells. Surprisingly, although $200 \mu$ M SNP virtually had no effect on the $\mathrm{Ng}$ promoter activity in Neuro-2a cells, it markedly suppressed Ng promoter activity in clone1 cells. Data on high dose of $2 \mathrm{mM}$ SNP stimulation was not obtained because both Neuro-2a and clone1 cells showed typical signs of apoptosis with round and shrunken shape. It is worthy to note that the reporter activity of $\mathrm{Ng}$ promoter were more than 2 folds higher in the Ng-expressed clone1 cells than those of the Ng-free Neuro-2a cells for the lower ranges of SNP treatments $(0.2 \mu \mathrm{M}$ to 20 $\mu \mathrm{M})$ and the control group without SNP treatment

(b)

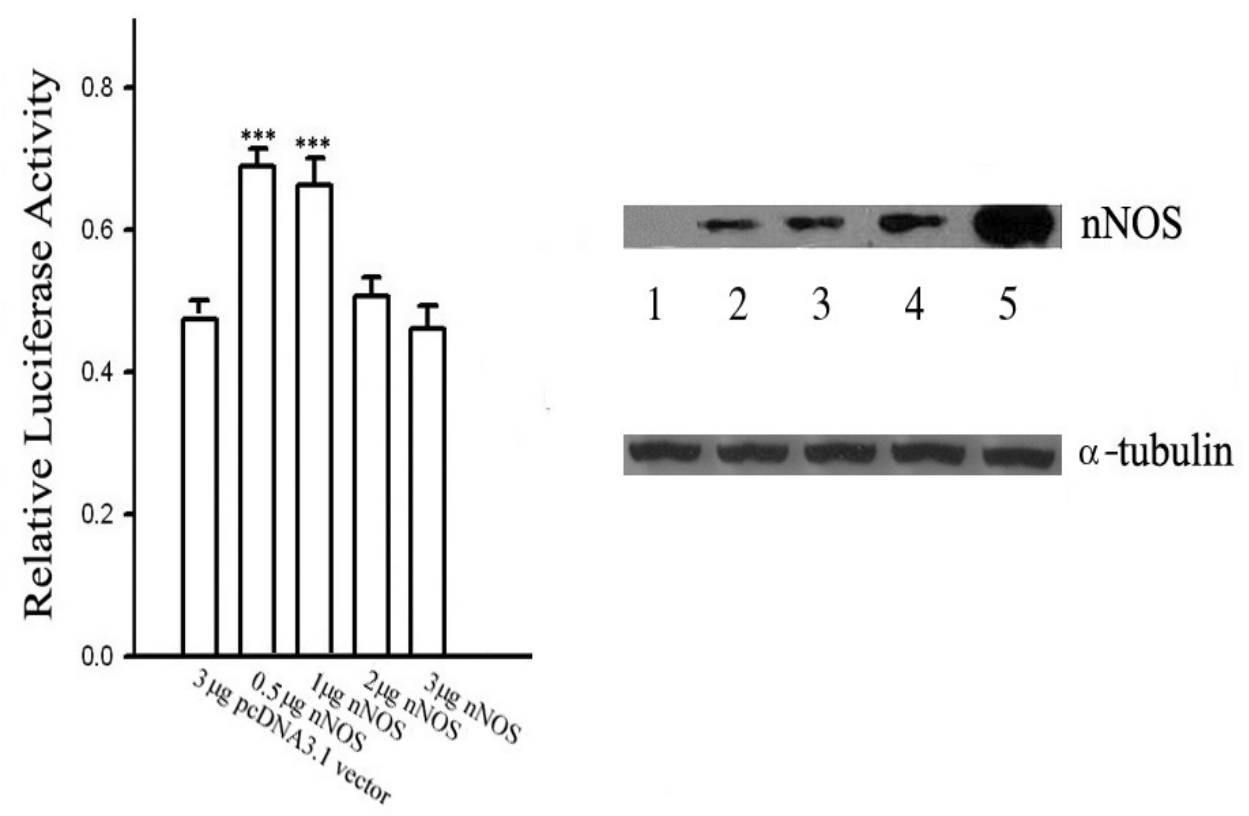

group. There was a slight increase in $\mathrm{Ng}$ promoter activity for both clone1 and Neuro-2a groups at the lowest $0.2 \mu \mathrm{M}$ treated SNP although it did not reach a significant level. To observe a dynamics of $\mathrm{Ng}$ promoter activity change in response to SNP stimulation, we compared $\mathrm{Ng}$ promoter activities in response to $200 \mu \mathrm{M}$ SNP treatments among Neuro-2a, clone1 and GT1-7 cells with a $30 \mathrm{~h}$ time course. As shown in Fig. $3 \mathrm{~b}, \mathrm{Ng}$ promoter activities were determined every $10 \mathrm{~h}$ after incubation of SNP in $4 \mathrm{~h}$ (i.e. $200 \mu \mathrm{M}$ SNP was applied during $20 \mathrm{~h}-24 \mathrm{~h}$ post-transfection of the promoter vector and then was washed away with fresh medium). The results revealed that the baseline of $\mathrm{Ng}$ promoter activity in different cell lines at the start point was different. The clone1 cells had the highest reporter activity among the three cells tested. However, at $30 \mathrm{~h}$ post-transfection, the $\mathrm{Ng}$ promoter activity in clone 1 cells decreased by $40 \%$ of its initial activity that was measured immediately before $200 \mu \mathrm{M}$ SNP application. $\mathrm{Ng}$ promoter activity continued to decrease to approximately $20 \%$ of its initial activity at $40 \mathrm{~h}$ post-transfection and kept constant from 40 to 50 h. In contrast, $\mathrm{Ng}$ promoter activity maintained virtually unchanged throughout the whole time course in either Neuro-2a or GT1-7 cells upon $4 \mathrm{~h}$ SNP treatment. The bifurcating response of $\mathrm{Ng}$ promoter activity to SNP stimulation between Ng-expressing cells and $\mathrm{Ng}$-free cells implied that $\mathrm{Ng}$ transcription was affected either by cell signaling or changed cell conditions caused by $\mathrm{Ng}$ expression. Based on our further observation, we found that at the time-point of $40 \mathrm{~h}$ post-transfection, most of clone1 cells were shrunk and showed a morphological abnormality. The extremely low promoter activity was actually resulting from the pathophysiological change of clone1 cells. 
Figure 3. SNP suppresses Ng promoter activity in the presence of $\mathrm{Ng}$ protein. (a) $\mathrm{Ng}$ promoter activities were measured in Neuro-2a and clone1 cells with stimulation of indicated concentrations of $4 \mathrm{~h}$ SNP treatment. Data were processed by one-way ANOVA and represented as means $\pm \operatorname{SEM}(\mathrm{n}=3)$. *** $\mathrm{p}<0.001$ (compared with clonel control). (b) $\mathrm{Ng}$ promoter activities were measured at various time points in indicated cell lines with either PBS or $200 \mu \mathrm{M}$ SNP treatment. PBS or SNP were applied to cultures $20 \mathrm{~h}$ post-transfection and incubated for $4 \mathrm{~h}$ followed by replacing with fresh medium. Data are shown as means $\pm \operatorname{SEM}(n=6)$.

\section{Ng expression promotes SNP-induced cell death}

In recent years, NO has received increasing attention for its implication in neuronal death, which is a feature of many neurological disorders. In the present study, we reasoned that $\mathrm{Ng}$ protein may enact an additional effect on the dys-regulation of calcium homeostasis resulting from the uncontrolled overdose of NO stimulation, and consequently, promotes NO-induced cell death. To test our conjecture, SNP stimulation of clone1 and Neuro-2a cells was conducted and the percentage of viable cells was determined by an MTT reduction assay. As shown in Fig. 4a, a $12 \mathrm{~h}$ prolonged stimulation with 0.2 and $2 \mu \mathrm{M}$ SNP promoted a slight proliferation of Neuro-2a cells while 20 and $200 \mu \mathrm{M}$ SNP caused a decrease in the viability of the cells. On the other hand, prolonged SNP stimulation induced cell death of the $\mathrm{Ng}$-expressing clone1 cells in a dose-dependent manner although at 0.2 and $2 \mu \mathrm{M}$ it only caused a slightly decrease in cell viability. Around $25 \%$ of clone1 cells suffered cell death at a 20 $\mu \mathrm{M}$ SNP treatment and virtually $50 \%$ of them died at a $200 \mu \mathrm{M}$ SNP treatment. At each concentration level of $\mathrm{SNP}$, clone1 cells were induced to death with a larger proportion than that of Ng-free Neuro-2a cells. The extreme difference of cell viability between Neuro-2a and clone 1 cells occurred at a $200 \mu \mathrm{M}$ SNP treatment, where cell viability in Neuro-2a cells was up to $85 \%$ of its untreated control level in comparison to that in clone1 cells which was only $50 \%$ of its control level. Apoptosis analysis revealed that DNA fragmentation was more easily induced in clone1 cells than in Neuro-2a cells upon a prolonged SNP stimulation. As depicted in Fig. $4 b$, while DNA fragmentation was found neither in clone1 nor Neuro-2a cells in response
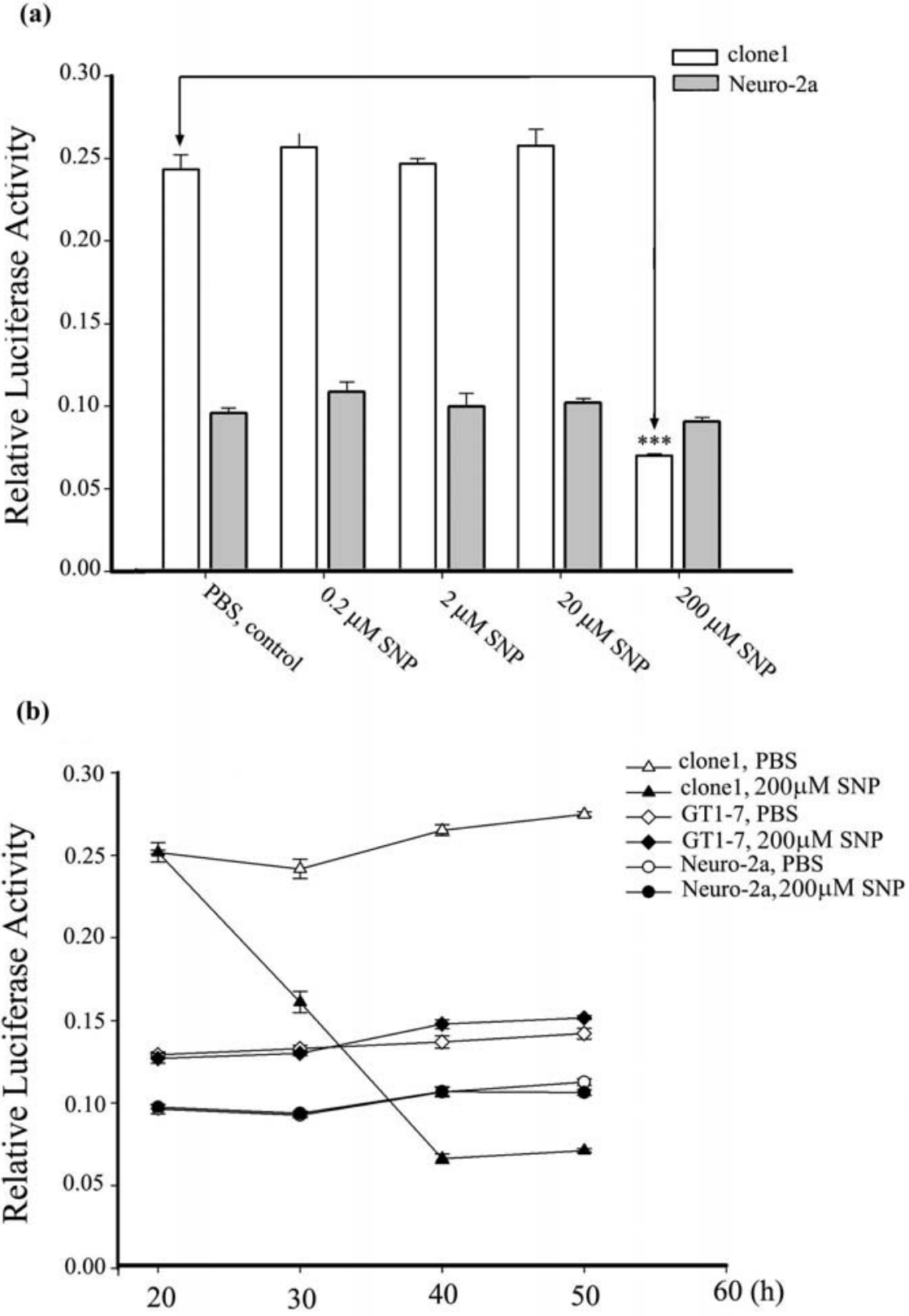

Timepoint of Post-transfection

to 0.2 or $2 \mu \mathrm{M}$ SNP treatment (lane 1 to 4 ), it was easily identified in clone1 cells subjected to a 20 or $200 \mu \mathrm{M}$ SNP treatment (lane 6 and 8). With this same treatment, a lesser degree of DNA fragmentation was found in Neuro-2a cells (lane 5 and 7). These assays revealed that $\mathrm{Ng}$ expression synergistically promotes the SNP-induced apoptotic action on Neuro-2a cells. We then asked the question whether a cytotoxicity conferred by elevated intracellular calcium could also be promoted by $\mathrm{Ng}$ expression. In so doing, we compared the cell viability of clone1 and Neuro-2a cells upon stimulation of a calcium ionophore, A23187. As shown in Fig. 4c, after $24 \mathrm{~h}$ incubation with A23187, a dose-dependent decrease in cell viability was found in both cell lines, but at each concentration level of A23187 $(0.5,1$, and $2 \mu \mathrm{M})$, clone 1 cells exhibited a greater potentiality of death than Neuro-2a cells $(60 \%$ 
vs. $80 \%, 40 \%$ vs. $70 \%$ and $20 \%$ vs. $60 \%$, respectively). Hence, we compared SNP-induced cell death among These assays indicate that with the expression of $\mathrm{Ng}$ the cell becomes more susceptible to a given extracellular calcium influx leading to cell death.

Figure 4. $\mathrm{Ng}$ promotes Neuro-2a cell death induced by prolonged SNP or A23187 stimulation. (a) Cell viability of Neuro-2a and clone1 cells was determined by MTT assay after $12 \mathrm{~h}$ stimulation with various concentrations of SNP. (b) Detection of DNA fragmentation induced by prolonged SNP stimulation (12 h) in Neuro-2a and clone1 cells. Lanes 1, 3, 5, 7 correspond to Neuro-2a cells treated with 0.2 , 2, 20, $200 \mu \mathrm{M}$ SNP, respectively. Lanes $2,4,6,8$ correspond to clone 1 cells treated with $0.2,2,20,200 \mu \mathrm{M}$ SNP, respectively. Lane $9,1 \mathrm{~kb}$ DNA ladder. (c) Cell viability of Neuro-2a and clone1 cells were determined by MTT assay after $24 \mathrm{~h}$ stimulation with various concentrations of A23187. For panel a and c, the cell viability was calculated by the following equation: MTT OD value of sample/MTT OD value of control (cell treated with PBS). Data are shown as means \pm SEM $(n=6)$.

\section{A functional IQ motif of $\mathrm{Ng}$ is required for pro- moting SNP-induced cell death}

Like other IQ motif-containing CaM-binding proteins [28], $\mathrm{Ng}$ exerts its functions by interacting

(a)

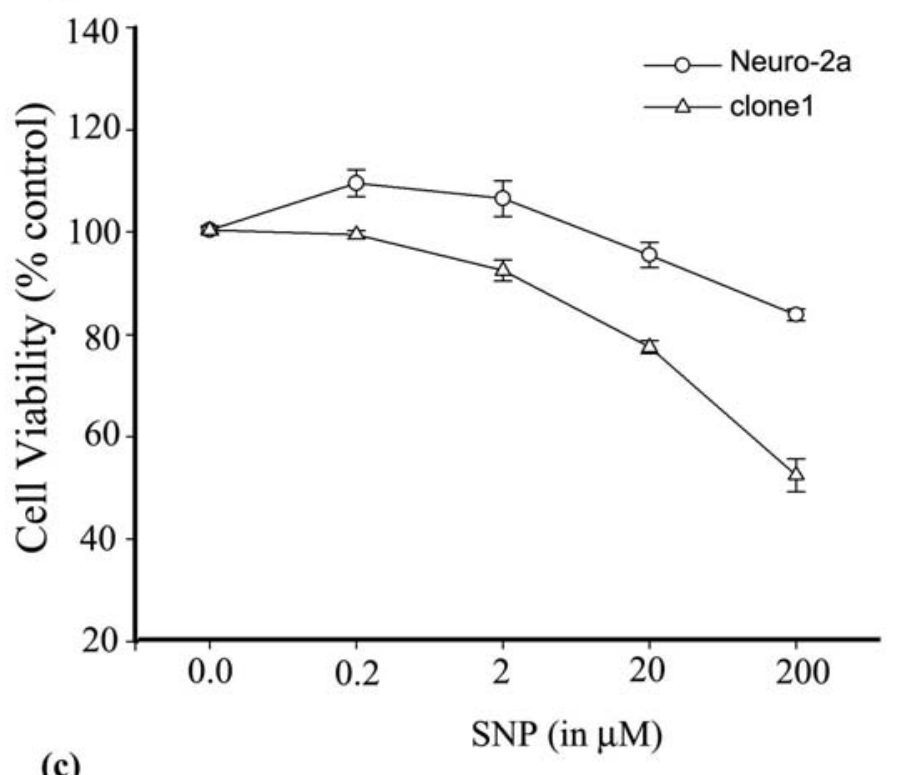

(c)

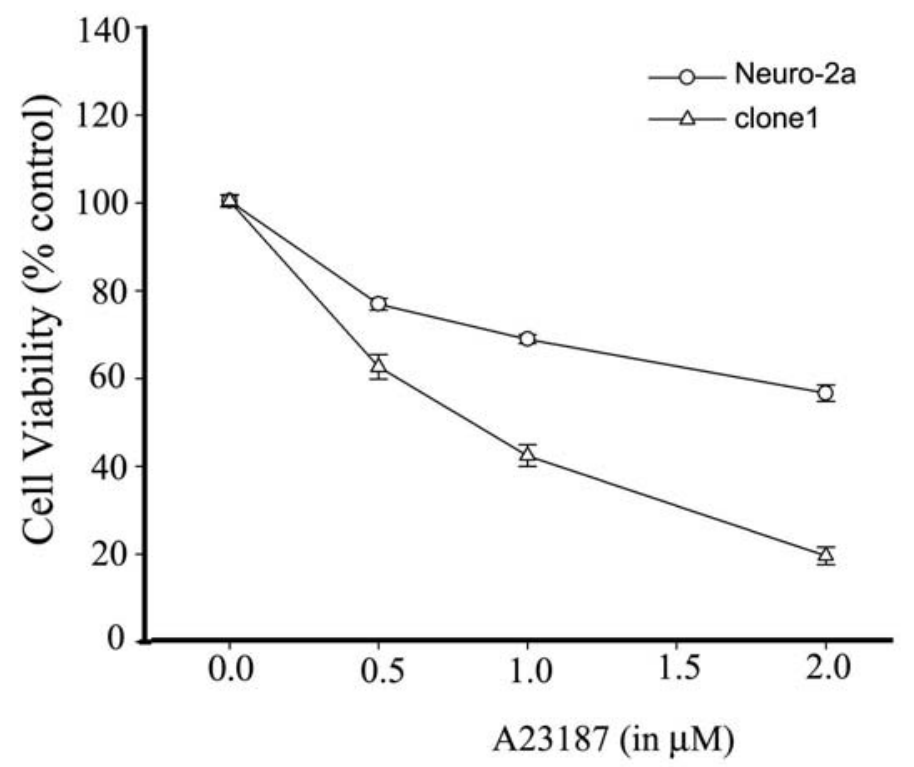

(b)

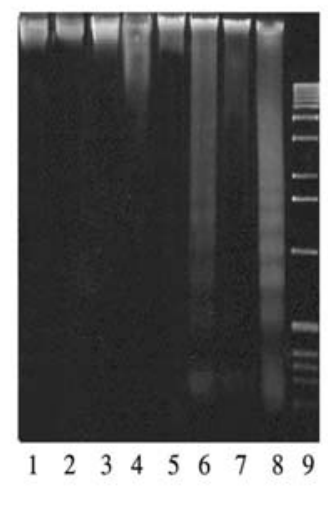
with CaM at the IQ motif. Now that our results have shown that $\mathrm{Ng}$ expression promotes SNP-induced cell death, we further attempted to elucidate the role of $\mathrm{Ng}$-CaM interaction in promoting cell death. As oxidized $\mathrm{Ng}$ has a reduced affinity for CaM, we were also interested in examining which factor, the oxidizable Cys residues or the CaM interacting IQ motif of $\mathrm{Ng}$ has any relevance to the Ng-promoted SNP-induced cell death. To answer these questions, we made two site-directed mutants of $\mathrm{Ng}$ expression plasmid based on previous reports. One plasmid was to make a specific single amino acid substitution $\left(I_{33}\right.$ to $\left.Q\right)$ in the IQ motif to ablate the binding of $\mathrm{Ng}$ to $\mathrm{CaM}$ in vivo [4]. The other was to disrupt all four Cys residues in the $\mathrm{Ng}$ protein sequence to abolish the oxidation [6].

cells expressing wild type (WT), I33Q mutant or Cys mutant Ng. The survivability of Neuro-2a cells transiently transfected with $\mathrm{WT}$ or $\mathrm{Ng}$ mutants were assessed by MTT reduction assay after $12 \mathrm{~h}$ prolonged incubation with $200 \mu \mathrm{M}$ SNP. The bar chart in Fig. 5a showed that Neuro-2a cells expressing WT Ng suffered a severe NO-induced cell death and the cell viability reached less than $60 \%$ of the control level (the control group is Neuro-2a cells transfected with pIRES2-EGFP vector). In contrast, Neuro-2a expressing I33Q mutant $\mathrm{Ng}$ obtained cell viability at $90 \%$ of the control level. Much to our surprise, Neuro-2a cells expressing Cys mutant $\mathrm{Ng}$ also suffered a massive cell death upon prolonged stimulation with $200 \mu \mathrm{M}$ SNP. The degree of cell death was quite similar to that of 
cells expressing WT Ng. Cys mutant Ng lacking all four Cys residues was resolved on $10-20 \%$ non-reducing gradient SDS-PAGE with disappearance of the fast mobility shift band which is the oxidized form of $\mathrm{Ng}$ (Fig 5a, lane 4). Expression of WT $\mathrm{Ng}$ or I33Q mutant $\mathrm{Ng}$ in Neuro-2a cells resulted in both reduced and oxidized forms (Fig 5a, lane 2 and 3 , respectively). This assay in the first place evidenced that $\mathrm{Ng}$ with a disrupted IQ motif was unable to promote SNP-induced cell death and implied that a functional IQ motif is indispensable for this promoting effect. Secondly, in this assay, abolishing $\mathrm{Ng}$ oxidation did not salvage the SNP-induced cell death. The Cys mutant Ng that still contains a functional IQ motif may be a good indication for this phenomenon.

Figure 5. A functional IQ motif in $\mathrm{Ng}$ is required for promoting intracellular calcium increase and NO-induced cell death. (a) Following transfection with different forms of $\mathrm{Ng}$ cDNA constructed into pIRES2-EGFP vector, Neuro-2a cells were treated with $200 \mu \mathrm{M}$ SNP for $12 \mathrm{~h}$. Cell viability was measured by MTT reduction assay. Data were normalized by densitometric scanning of film from Western blotting against EGFP. Data were represented as $\%$ of the control (normalized MTT reading from Neuro-2a cells transfected with pIRES2-EGFP vector). Data shown are means $\pm \operatorname{SEM}(\mathrm{n}=6) . * * * \mathrm{p}<0.001$ (compared with the vector control by Student's $t$-test). Transient expression of variations of $\mathrm{Ng}$ in Neuro-2a cells were resolved on $10 \%$ to $20 \%$ gradient non-reduced PAGE and subjected to Western blotting against $\mathrm{Ng}$ antibodies. Lane 1, transfected with pIRES2-EGFP vector; 2, transfected with WT Ng cDNA; 3, transfected with I33Q Ng cDNA; 4, transfected with Cys mutant Ng cDNA. (b) Following transfections, Neuro-2a cells were loaded with x-rhod-1, and successfully transfected cells were identified by a green fluorescence filter and chosen as region of interest (ROI). Fluorescence changes were monitored using a filter for $\mathrm{x}$-rhod-1. Representative normalized $\left(\mathrm{F} / \mathrm{F}_{0}\right)$ fluorescence changes versus time are shown in the line plot. Arrow indicates the SNP application time. The bar chart shows averaged peak fluorescence changes from various transfections indicated in response to $200 \mu \mathrm{M}$ SNP. Data shown are means \pm SEM ( $\mathrm{n}=9$ for all transfections). ${ }^{* * *} \mathrm{p}<0.001$ obtained from Student's t test (compared with the data from pIRES2-EGFP transfection).

Once it was known that $\mathrm{Ng}$ promoted SNP-induced cell death requires the IQ motif/CaM interaction, it was logical to explore if intracellular calcium homeostasis is changed by $\mathrm{Ng}$ upon SNP stimulation. We achieved this by using a calcium fluorescence dye rhod-x- 1 to monitor the intracellular calcium change upon $200 \mu \mathrm{M}$ of SNP stimulation in Neuro-2a cells transiently expressing WT Ng or $\mathrm{Ng}$ mutants. The fluorescence intensity plot in Fig. $5 \mathrm{~b}$ showed that $200 \mu \mathrm{M}$ SNP induced a rapid intracellular calcium increase in Neuro-2a cells expressing WT Ng or Cys mutant $\mathrm{Ng}$, while it only aroused a small and slow calcium increase in Neuro-2a cells transfected with I33Q Ng cDNA or pIRES2-EGFP vector as control. The bar chart in Fig. $5 b$ showed (a)
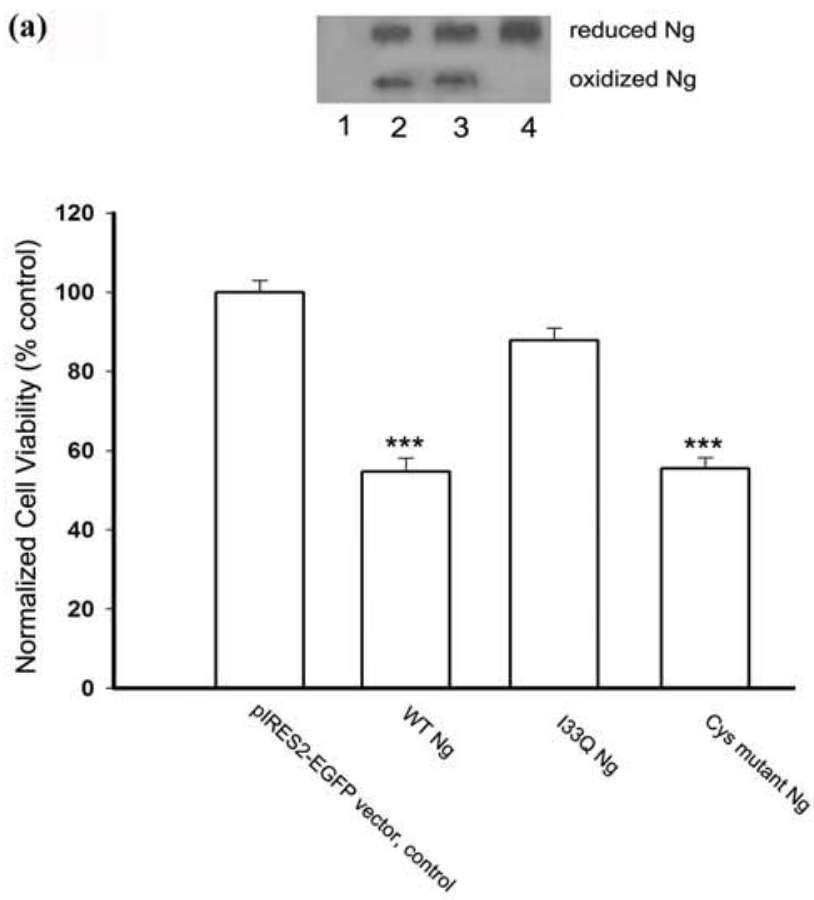

(b)
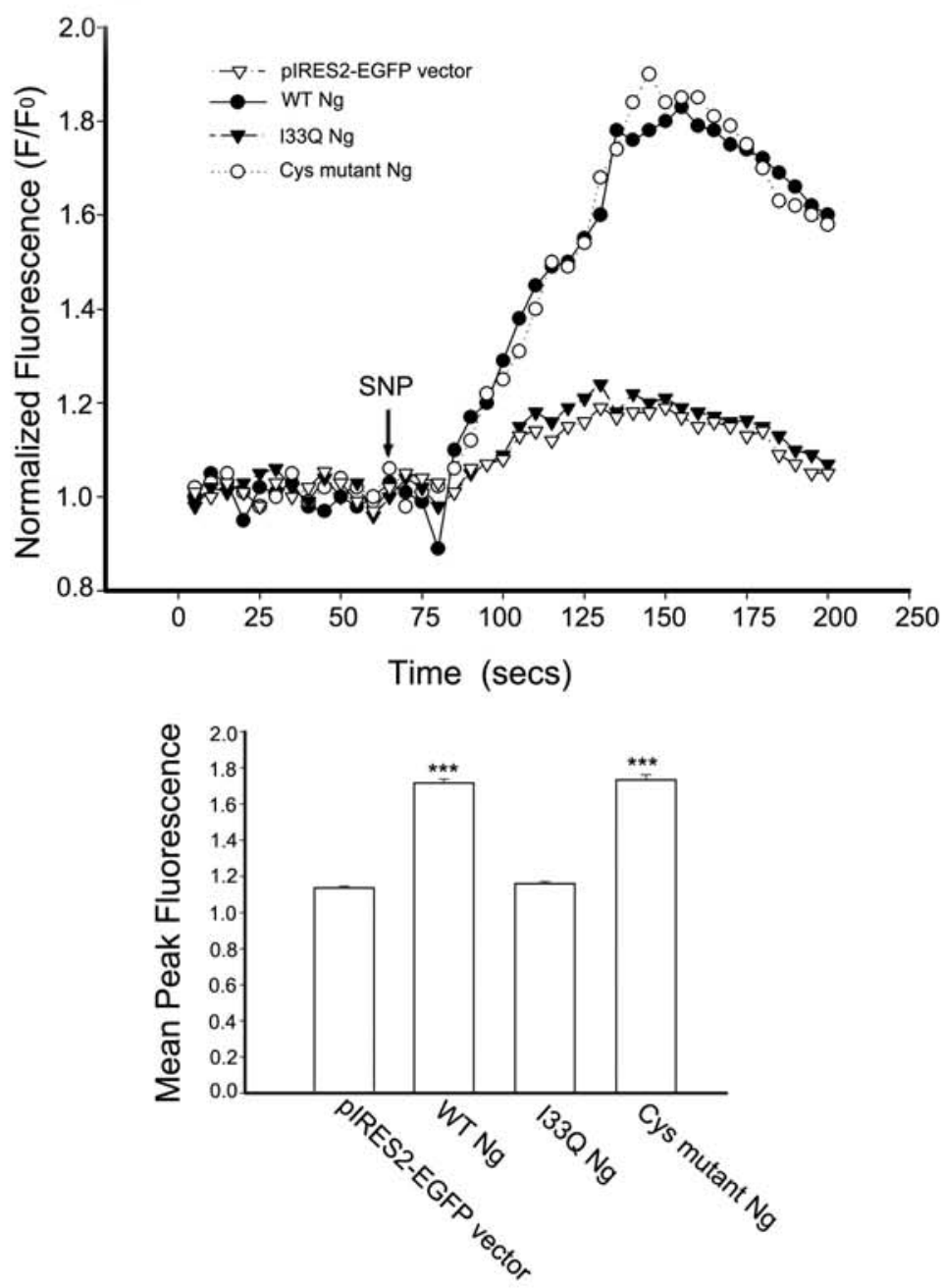
that the average peak of fluorescence derived from a fluorescence intensity plot. Average peak responses from a number of cells $(n=9)$ illustrated that in response to SNP stimulation, there was no significant difference of intracellular calcium changes between Neuro-2a cells transfected with I33Q Ng and those transfected with pIRES2-EGFP control vector. In contrast, the average peak response from cells transfected with WT Ng or Cys mutant Ng showed a dramatically larger increase in intracellular calcium than that of control cells. These results suggest that $\mathrm{Ng}$ promotes SNP-induced cell death most likely through amplifying the intracellular calcium increase. Interaction between IQ motif and CaM is implicated in this $\mathrm{Ng}$ promoted amplification of calcium signaling.

\section{Discussion}

NO is thought to be involved in regulating neurogenesis, synaptic plasticity, LTP and learning and memory $[29,30]$. Ng is a brain-specific protein implicated in learning and memory and regulates neural plasticity and LTP. The correlated role of NO production and $\mathrm{Ng}$ transcriptional regulation possibly accounts for parts of these neuronal functions. The present study showed for the first time that $\mathrm{Ng}$ transcription could be regulated either by exogenous NO released by NO donors or endogenous NO production from nNOS. Based on $\mathrm{Ng}$ promoter analysis, we demonstrated that NO, released by various $\mathrm{NO}$ donors, changes $\mathrm{Ng}$ promoter activity in mammalian cells in a differential way. Among the NO donors we tested, SNAP, SIN-1.HCL and NOR-3 were able to up-regulate $\mathrm{Ng}$ promoter while NOC-7, NOC-9 and Spermine NONOate were not able to change Ng promoter activity. The other two NO donors, SNP and 4-Phenyl-3-furoxancarbonitrile, at our experiment condition (24 h incubation), showed harmful effect on the cells and caused massive cell death. The most stable NO donor NOR-3 in our experiment stimulated $\mathrm{Ng}$ promoter activity with the largest extent. By real-time PCR, Ng mRNA abundance was elevated by NOR-3 stimulation in primary cortical neurons. This is an evidence that $\mathrm{Ng}$ transcriptional activity could be enhanced by exogenous NO stimulation. By using a pharmaceutical drug that selectively inhibits sGC, the upregulation of $\mathrm{Ng}$ transcription by $\mathrm{NO}$ was attributed to the sGC-dependent pathway. Data from the nNOS cotransfection experiment revealed how $\mathrm{Ng}$ promoter activity was largely dependent on how much the nNOS expressed in the cell. At lower expression level of $\mathrm{nNOS} \mathrm{Ng}$ promoter activity was enhanced whereas at higher expression level of nNOS $\mathrm{Ng}$ promoter activity was restored to its basal level. In the CNS, NO production is preferentially activated by calcium influx through N-methyl-D-aspartate (NMDA) receptors [31]. PSD-95 assembles a protein complex containing nNOS and NMDA receptors in postsynaptic neurons. The coupled activation of NMDA and nNOS strictly regulates the NO production [32]. It was reported that $\mathrm{Ng}$ was oxidized by activation of NMDA receptors in mouse hippocampal slices [33]. It is possible that the activation of NMDA receptors by presynaptic glutamate signaling could up-regulate $\mathrm{Ng}$ transcription through nNOS activation while overactivation of NMDA receptors dampens $\mathrm{Ng}$ transcription due to overproduction of NO by nNOS. The transcriptional regulation of $\mathrm{Ng}$ followed by $24 \mathrm{hr}$ of exogenous and endogenous NO treatment reported here could be an effector to fine-tune the late phase of neuronal plasticity. Recently, Huang et al [34] reported that environmental enrichment boosts $\mathrm{Ng}$ expression and in turn enhances hippocampal learning and memory. Even though $\mathrm{Ng}$ is an abundant protein in postsynaptic neuron, it is likely the transcription and expression level of $\mathrm{Ng}$ in adult could be modulated by certain stimulations. It is also very likely that $\mathrm{Ng}$ expression is regulated in certain development stage; especially further studies are needed to clarify whether $\mathrm{NO}$ plays the role in the process of $\mathrm{Ng}$ up-regulation 1 or 2 weeks after birth when its expression level is rapidly reaching the adult level.

Furthermore, by using a stably Ng-expressing Neuro-2a cell line (clone1), we found that Ng promoter activity could be differentially affected by SNP depending on the presence or absence of $\mathrm{Ng}$. With 200 $\mu \mathrm{M}$ SNP stimulation, the activity of $\mathrm{Ng}$ promoter in Ng-expressing cells was dramatically suppressed while it remained unchanged in $\mathrm{Ng}$-free cells. It has been shown that in pathophysiological conditions like ischemia, a dramatic and selective loss of $\mathrm{Ng}$ mRNA occurred in the brain [35]. As a matter of fact, after $4 \mathrm{~h}$ stimulation with $200 \mu \mathrm{M}$ SNP some clone1 cells showed a sign of neurite retraction and cell rounding. Thus, we speculated that the SNP-mediated decrease in $\mathrm{Ng}$ promoter activity possibly resulted from a pathophysiological change of Ng-expressing cells caused by SNP insult. To test the possibility whether $\mathrm{Ng}$ promotes the pathophysiological changes of the cells, we compared the cell viability of $\mathrm{Ng}$-expressing Neuro-2a cells (clone1) and of Ng-free Neuro-2a cells with a $12 \mathrm{~h}$ prolonged stimulation of SNP. Our results obtained from cell viability and DNA fragmentation assays revealed that the Ng-expressing Neuro-2a cells are more susceptible to prolonged SNP stimulation. It has been shown that ectopic expression of $\mathrm{Ng}$ in IL-2-dependent $T$ cells induces apoptosis [22]. The present study demonstrates another instance that $\mathrm{Ng}$ acts as a pro-apoptotic factor in SNP-induced cell death. Interestingly, increased expression of GAP-43, a presynaptic counterpart of $\mathrm{Ng}$, also induces neuronal apoptosis [36]. Transgenic mice with over-expression of GAP-43 were found to have a reduction in the total number of neurons in various brain regions due to apoptosis [37]. Data on transgenic mice with over-expression of $\mathrm{Ng}$ are lacking. Yet based on the present data, it is tempting to suggest that it is quite likely that $\mathrm{Ng}$ and GAP-43 may perform similar physiological functions to regulate the number of neurons in selected regions during the CNS development.

Calcium ion is an important intracellular messenger enabling various physiological processes. In 
the nervous system, for example, changes in the intracellular free calcium concentration can play a role in postsynaptic physiology, in presynaptic neurosecretion and in the rate of metabolic catabolism [38, 39]. However, uncontrolled increases in cytosolic calcium in neurons can also contribute to excitotoxicity and neuronal death $[40,41]$. Study of neurons from $\mathrm{Ng}-/-$ mice showed that the absence of $\mathrm{Ng}$ alters neuronal $\mathrm{Ca}^{2+}$ dynamics including baseline $\mathrm{Ca}^{2+}$ levels [42]. Heterologous expression of $\mathrm{Ng}$ was shown to change the mobilization of intracellular $\mathrm{Ca}^{2+}$ in Xenopus oocytes [43]. It was suggested that the higher the $\mathrm{Ng}$ concentration, the more $\mathrm{Ng}$-CaM complexes will be formed, which effectively raises $\mathrm{Ca}^{2+}$ at given $\mathrm{Ca}^{2+}$ influx [3]. By using the calcium inophore A23187 to facilitate the calcium influx of the cell, we demonstrated that the presence of $\mathrm{Ng}$ increases the likelihood of cellular apoptosis for a given calcium influx. This finding suggests that an amplified response to a given calcium influx is a cause of Ng-promoted SNP-induced cell death. A number of lines of evidence support that the NO donors exert their various functions through regulating intracellular free $\mathrm{Ca}^{2+}$ ho- meostasis [44, 45]. We can not exclude the possibility that the SNP-induced cell death may, if not solely, at least partially result from cyanide and iron degraded from SNP other than NO [46,47]. Nevertheless, from our experiment, the evidence of SNP-induced intracellular $\mathrm{Ca}^{2+}$ increase in Ng-expressing cell is substantial. Based on the current findings we suggest that the vulnerability of $\mathrm{Ng}$-expressing cells to prolonged SNP stimulation is a result of $\mathrm{Ng}$-amplified $\mathrm{Ca}^{2+}$ signaling initiated by SNP-induced $\mathrm{Ca}^{2+}$ homeostasis change. $\mathrm{Ng}$ has been proposed to modulate $\left[\mathrm{Ca}^{2+}\right]_{\mathrm{i}}$ by the 'mass-action', i.e., the more expression of $\mathrm{Ng}$, the higher $\mathrm{Ca}^{2+}$ transients under given stimulus-induced $\mathrm{Ca}^{2+}$ influx [3]. We proposed that when excitatory glutamate signal was received by NMDA receptors in the postsynaptic neuron, CaM-buffering $\mathrm{Ng}$ elevates the $\mathrm{Ca}^{2+}$ transient. This amplified $\mathrm{Ca}^{2+}$ transient itself may directly induce apoptosis or/and promote the dissociation of $\mathrm{CaM}$ from $\mathrm{Ng}$ to make more $\mathrm{Ca}^{2+} / \mathrm{CaM}$ complex available for sustaining the activated nNOS, which then make excessive production of $\mathrm{NO}$ that causes neuronal death (Fig 6).

Figure 6. A hypothetic role of $\mathrm{Ng}$ in NMDA receptor-mediated neuronal death. The activation of NMDA receptor by excitatory presynaptic signal cause $\mathrm{Ca}^{2+}$ transient in neuron which can be amplified by the 'mass action' of $\mathrm{Ng}$. The overacting $\mathrm{Ca}^{2+}$ transients induce neuronal death by itself or cause the dissociation of $\mathrm{CaM}$ from $\mathrm{Ng}$ and form more $\mathrm{Ca} / \mathrm{CaM}$ complex which sustains the NMDA-mediated activation of nNOS which implicates dephophorylation of nNOS by calcineurin. This sustained over-activation of $\mathrm{nNOS}$ then produce overdose $\mathrm{NO}$ which induces neuronal apoptosis.

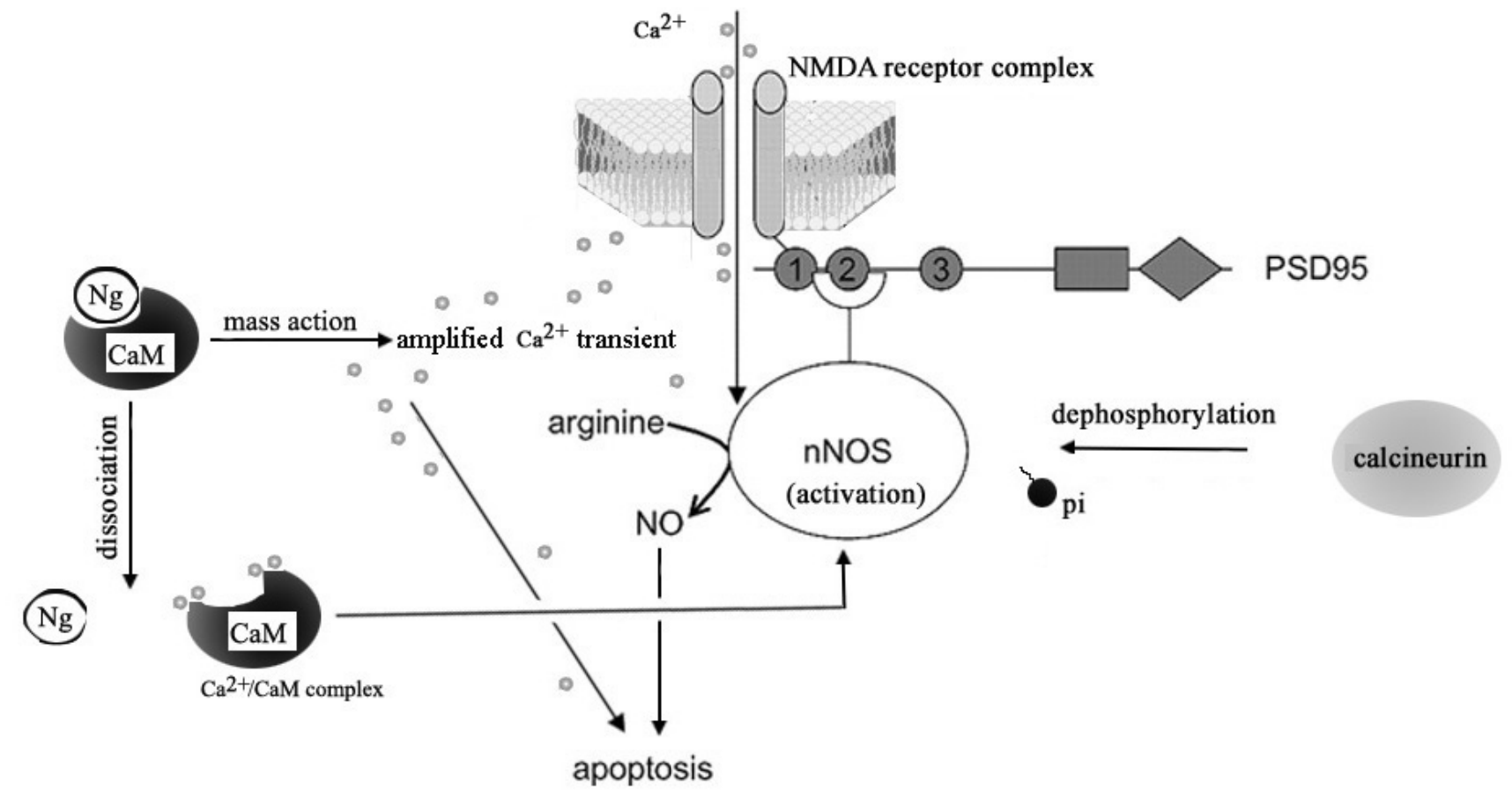

It has been shown that the homeostatic tuning of $\mathrm{Ca}^{2+}$ by $\mathrm{Ng}$ implicates the interaction between CaM and the IQ motif of $\mathrm{Ng}[48,49]$. In the present study, we asked whether $\mathrm{Ng}$ promotes SNP-induced cell death through interaction between an IQ motif and CaM. Cell survival experiments indicated that disruption of the $\mathrm{Ng}$ IQ motif dramatically inhibited the promotive effect of $\mathrm{Ng}$ on SNP-induced cell death. This finding agrees with the result obtained from a study of IL-2 dependent T cells that IQ-disrupted $\mathrm{Ng}$ unable to bind CaM eliminates the apoptotic effect of $\mathrm{Ng}$ [22]. Single cell calcium imaging further confirmed our hypothesis that an intracellular calcium increase as a result of interaction between $\mathrm{CaM}$ and the functional IQ motif of $\mathrm{Ng}$ is essential for promoting 
SNP-induced cell death. Intracellular calcium concentration was dramatically increased by SNP stimulation in Neuro-2a cells expressing WT Ng, while it was basically unchanged in Neuro-2a cells expressing IQ mutant $\mathrm{Ng}$. Since all four Cys residues (oxidization sites) reside outside the IQ motif of $\mathrm{Ng}$, the oxidization of $\mathrm{Ng}$, though reduces $\mathrm{Ng}$ affinity for $\mathrm{CaM}$, does not destruct the integrity of IQ motif. Therefore, we interpreted that abolishing the oxidation of $\mathrm{Ng}$ by mutating all Cys residues would not attenuate the severity of Ng-promoted SNP-induced death. The cell viability assay for Neuro-2a cells transfected with four Cys mutant $\mathrm{Ng}$ confirmed this reasoning. The survival rate of these cells upon prolonged SNP stimulation was comparable to Neuro-2a cells expressing WT Ng. Data from single cell image experiment showed that increase in intracellular calcium concentration in Neuro-2a cells expressing Cys mutant $\mathrm{Ng}$ could be normally induced in a way similar to that in Neuro-2a cells expressing WT $\mathrm{Ng}$. These findings suggest that oxidation of $\mathrm{Ng}$ does not participate as a critical factor in the process of $\mathrm{Ng}$-promoted SNP-induced cell death. It has been shown that oxidation of $\mathrm{Ng}$ in the brain slice occurred only in a transient manner upon NMDA or NO donor stimulation [50] and is responding to physiological signaling. In contrast, a long lasting change of cell status, such as pathophysiological insult due to high oxidative stress, may trigger an apoptotic fate that recruits mechanisms other than the oxidation of $\mathrm{Ng}$.

Since $\mathrm{Ng}$ is expressed in specific brain regions critical for learning and memory, this high-demanding function imperatively requires a lower threshold for external stimuli to neurons. Based on the current findings, we proposed that $\mathrm{Ng}$ acts as a calcium signal amplifier by interaction with CaM through its IQ motif, rendering the neuron a high sensitivity to calcium change. This high calcium sensitivity, just like a two-edge sword, confers enhanced plasticity of neurons as well as increased susceptibility to pathophysiological stimuli resulted from overacting of NMDA receptors and oxidative stresses.

\section{Acknowledgments}

We thank Dr. Huang Kuo-Ping (NIH) for pET3b-Ng plasmid, Dr. Rohini Kuner (University of Heidelberg, Germany) for pcDNA3.1-nNOS plasmid, and Dr. Pamela Mellon (UCSD) for GT1-7 cells. This work was supported in part by a grant from the Ministry of Education Singapore via the University Research Council of the National University of Singapore R-154-000-228-112 to F.-S. S.

\section{Conflict of Interests}

The authors have declared that no conflict of interest exists

\section{References}

1. Gerendasy D.D., and Sutcliffe J.G. RC3/neurogranin, a postsynaptic calpacitin for setting the response threshold to calcium influxes. Mol. Neurobiol.1997 15:131-163.

2. Pak J.H., Huang F.L., Li J., Balschun D., Reymann K.G., Chiang
C., Westphal H., Huang K.P. Involvement of neurogranin in the modulation of calcium/calmodulin-dependent protein kinase II, synaptic plasticity, and spatial learning: a study with knockout mice. Proc. Natl. Acad. Sci. USA 2000 97: 11232-11237.

3. Huang K.P., Huang F.L., Jager T., Li J., Reymann K.G., Balschun D. Neurogranin/RC3 enhances long-term potentiation and learning by promoting calcium-mediated signaling. J. Neurosci. 2004 24:10660-10669.

4. Prichard L., Deloulme J.C., Storm D.R. Interactions between neurogranin and calmodulin in vivo. J. Biol. Chem. 1999 274: 7689-7694.

5. Huang K.P., Huang F.L., Chen H.C. Characterization of a 7.5-kDa protein kinase $\mathrm{C}$ substrate (RC3 protein, neurogranin) from rat brain. Arch Biochem Biophys. 1993 305: 570-580.

6. Mahoney C.W., Pak J.H., Huang K.P. Nitric oxide modification of rat brain neurogranin. Identification of the cysteine residues involved in intramolecular disulfide bridge formation using site-directed mutagenesis. J Biol Chem. 1996 271: 28798-28804.

7. Sheu F.S., Mahoney C.W., Seki K., Huang K.P. Nitric oxide modification of rat brain neurogranin affects its phosphorylation by protein kinase C and affinity for calmodulin. J. Biol. Chem.1996 271: 22407-22413.

8. Enderlin V., Pallet V., Alfos S., Dargelos E., Jaffard R., Garcin H., Higueret P. Age-related decreases in mRNA for brain nuclear receptors and target genes are reversed by retinoic acid treatment. Neurosci. Lett. 1997 229:125-129.

9. Husson M., Enderlin V., Alfos S., Feart C., Higueret P., Pallet V. Triiodothyronine administration reverses vitamin A deficiency-related hypo-expression of retinoic acid and triiodothyronine nuclear receptors and of neurogranin in rat brain. Br. J. Nutr. 2003 90: 191-198.

10. Etchamendy N., Enderlin V., Marighetto A., Vouimba R.M., Pallet V., Jaffard R., Higueret P. Alleviation of a selective age-related relational memory deficit in mice by pharmacologically induced normalization of brain retinoid signaling. J. Neurosci. 2001 21: 6423-6429.

11. Mons N., Enderlin V., Jaffard R., Higueret P. Selective age-related changes in the PKC-sensitive, calmodulin-binding protein, neurogranin, in the mouse brain. J. Neurochem. 200179 : 859-867.

12. Feart C., Mingaud F., Enderlin V., Husson M., Alfos S., Higueret P., Pallet V. Differential effect of retinoic acid and triiodothyronine on the age-related hypo-expression of neurogranin in rat. Neurobiol. Aging 2005 26: 729-738.

13. Martinez de A.C., Morte B., Coloma A., Bernal J. The human RC3 gene homolog, NRGN contains a thyroid hormone-responsive element located in the first intron. Endocrinology 1999 140: 335-343.

14. Morte B., Martinez de A.C., Manzano J., Coloma A., Bernal J. Identification of a cis-acting element that interferes with thyroid hormone induction of the neurogranin (NRGN) gene. FEBS Lett. 1999 464: 179-183.

15. Morte B., Iniguez M.A., Lorenzo P.I., Bernal J. Thyroid hormone-regulated expression of RC3/neurogranin in the immortalized hypothalamic cell line GT1-7. J. Neurochem. 1997 69: 902-909.

16. Sato T., Xiao D.M., Li H., Huang F.L., Huang K.P. Structure and regulation of the gene encoding the neuron-specific protein kinase C substrate neurogranin (RC3 protein). J. Biol. Chem. 1995 270:10314-10322.

17. Gui J., Song Y., Han N.L., Zhou S.F., Sheu F.S. Involvement of the GC-rich sequence and specific proteins (Sp1/Sp3) in the basal transcription activity of neurogranin gene. Biochem. Biophys. Res. Commun. 2006 345: 124-32.

18. Huang K.P., Huang F.L., Li J., Schuck P., McPhie P. Calcium-sensitive interaction between calmodulin and modified forms of rat brain neurogranin/RC3. Biochemistry 2000 39: 
7291-7299.

19. Bogdan C. Nitric oxide and the regulation of gene expression. Trends Cell Biol. 2001 11: 66-75.

20. Dawson V.L., Dawson T.M. Nitric oxide in neurodegeneration. Prog. Brain Res. 1998 118: 215-229.

21. Guix F.X., Uribesalgo I., Coma M., Munoz F.J. The physiology and pathophysiology of nitric oxide in the brain. Prog. Neurobiol. 2005 76:126-152

22. Devireddy L.R., Green M.R. Transcriptional program of apoptosis induction following interleukin 2 deprivation: identification of RC3, a calcium/calmodulin binding protein, as a novel proapoptotic factor. Mol. Cell Biol. 2003 23: 4532-4541.

23. Nishida Y., Yoshioka M., and St-Amand J. The top 10 most abundant transcripts are sufficient to characterize the organs functional specificity: evidences from the cortex, hypothalamus and pituitary gland. Gene 2005 344: 133-141.

24. Yang H.M., Lee P.H., Lim T.M., Sheu F.S. Neurogranin expression in stably transfected N2A cell line affects cytosolic calcium level by nitric oxide stimulation. Brain Res. Mol. Brain. Res. 2004 129: 171-178.

25. Mayer B. Regulation of nitric oxide synthase and soluble guanylyl cyclase. Cell Biochem. Funct. 1994 12: 167-177.

26. McDonald L.J., Murad F. Nitric oxide and cyclic GMP signaling. Proc. Soc. Exp. Biol. Med. 1996 211: 1-6.

27. Garthwaite J., Southam E., Boulton C.L., Nielsen E.B., Schmidt K., Mayer B. Potent and selective inhibition of nitric oxide-sensitive guanylyl cyclase by $1 \mathrm{H}-[1,2,4]$ oxadiazolo[4,3-a]quinoxalin-1-one. Mol. Pharmacol. 1995 48:184-188.

28. Bahler M., Rhoads A. Calmodulin signaling via the IQ motif. FEBS Lett . 2002 513: 107-113.

29. Holscher C. Nitric oxide, the enigmatic neuronal messenger: its role in synaptic plasticity. Trends Neurosci. 1997 20: 298-303.

30. Hawkins R.D., Son H., Arancio O. Nitric oxide as a retrograde messenger during long-term potentiation in hippocampus. Prog. Brain Res. 1998 118: 155-172.

31. Yun HY, Dawson VL, Dawson TM. Nitric oxide in health and disease of the nervous system. Mol. Psychiatry. 1997 2: 300-310.

32. Christopherson K.S., Hillier B.J., Lim W.A., Bredt D.S. PSD-95 assembles a ternary complex with the N-methyl-D-aspartic acid receptor and a bivalent neuronal NO synthase PDZ domain. J. Biol. Chem. 1999 274: 27467-27473.

33. Wu J., Huang K.P., Huang F.L. Participation of NMDA-mediated phosphorylation and oxidation of neurogranin in the regulation of $\mathrm{Ca} 2+-$ and $\mathrm{Ca} 2+/$ calmodulin-dependent neuronal signaling in the hippocampus. J. Neurochem. 2003 86: 1524-1533.

34. Huang F.L., Huang K.P., Wu J., Boucheron C. Environmental enrichment enhances neurogranin expression and hippocampal learning and memory but fails to rescue the impairments of neurogranin null mutant mice. J. Neurosci. 2006 26: 6230-6237.

35. Shughrue P.J., Merchenthaler I. Estrogen prevents the loss of CA1 hippocampal neurons in gerbils after ischemic injury. Neuroscience 2003 116: 851-861.

36. Wehrle R., Caroni P., Sotelo C., Dusart I. Role of GAP-43 in mediating the responsiveness of cerebellar and precerebellar neurons to axotomy. Eur. J. Neurosci. 2001 13: 857-870.

37. Aigner L., Arber S., Kapfhammer J.P., Laux T, Schneider C., Botteri F., Brenner H.R., Caroni P. Overexpression of the neural growth-associated protein GAP-43 induces nerve sprouting in the adult nervous system of transgenic mice. Cell 1995 83: 269-278.

38. Miller R.J. Calcium signalling in neurons. Trends Neurosci. 1998 11: 415-419.

39. Dunlap K., Luebke J.I., Turner T.J. Identification of calcium channels that control neurosecretion. Science 1994 266: 828-831.

40. Choi D.W. Glutamate neurotoxicity and diseases of the nervous system. Neuron 1998 1: 623-634.

41. Trump B.F., Berezesky I.K. The role of cytosolic Ca2+ in cell injury, necrosis and apoptosis. Curr. Opin. Cell Biol. 1992 4: 227-232.

42. van Dalen J.J., Gerendasy D.D., de Graan P.N., Schrama L.H., Gruol D.L. Calcium dynamics are altered in cortical neurons lacking the calmodulin-binding protein RC3. Eur. J. Neurosci. 2003 18: 13-22.

43. Cohen R.W., Margulies J.E., Coulter P.M., Watson J.B. Functional consequences of expression of the neuron-specific, protein kinase C substrate RC3 (neurogranin) in Xenopus oocytes. Brain Res. 1993 627: 147-152.

44. Tsuji Y., Unno N., Menconi M.J., Smith M., Fink M.P. Nitric oxide donors increase cytosolic ionized calcium in cultured human intestinal epithelial cells. Shock 1996 6: 19-24.

45. Mishra O.P., ivoria-Papadopoulos M. Nitric oxide-mediated Ca++-influx in neuronal nuclei and cortical synaptosomes of normoxic and hypoxic newborn piglets. Neurosci. Lett. 2002 318: 93-97.

46. Schröder H. No Nitric Oxide for HO-1 from Sodium Nitroprusside. Mol Pharmacol. 2006 69: 1507-1509.

47. Kim H.J., Tsoy I., Park M.K., Lee Y.S., Lee J.H., Seo H.G., and Chang K.C. Iron Released by Sodium Nitroprusside Contributes to Heme Oxygenase-1 Induction via the cAMP-Protein Kinase A-Mitogen-Activated Protein Kinase Pathway in RAW 264.7 Cells. Mol Pharmacol. 2006 69: 1633-1640.

48. Gerendasy D. Homeostatic tuning of $\mathrm{Ca} 2+$ signal transduction by members of the calpacitin protein family. J. Neurosci. Res. 1999 58:107-119.

49. Krucker T., Siggins G.R., McNamara R.K., et al. Targeted disruption of RC3 reveals a calmodulin-based mechanism for regulating metaplasticity in the hippocampus. J. Neurosci. 2002 22: 5525-5535.

50. Li J., Pak J.H., Huang F.L., Huang K.P. N-methyl-D-aspartate induces neurogranin/RC3 oxidation in rat brain slices. J. Biol. Chem. 1999 274: 1294-1300. 